\title{
The effects of exopolymers on cell morphology and culturability of Leuconostoc mesenteroides during starvation
}

Received: 8 April 1999 / Received revision: 16 July 1999 / Accepted: 6 August 1999

\begin{abstract}
Biofilm formation by bacterial cells can be used to modify the subsurface permeability for the purpose of microbial enhanced oil recovery, bio-barrier formation, and in situ bioremediation. Once injected into the subsurface, the bacteria undergo starvation due to a decrease in nutrient supply and diffusion limitations in biofilms. To help understand the starvation response of bacteria in biofilms, the relationship between exopolymer formation and cell culturability was examined in a batch culture. The average cell diameter was observed to decrease from $0.8 \mu \mathrm{m}$ to $0.35 \mu \mathrm{m} 3$ days after starvation began. Cell chain fragmentation was also observed during starvation. Cells that underwent starvation in the presence of insoluble exopolymers showed a slower rate of decrease in cell diameter and in cell chain length than cells without insoluble exopolymers. The rate of decrease in the average cell diameter and cell chain length were determined using a first order decay model. Cells starved in the presence of exopolymers showed greater culturability than cells starved without exopolymers. After 200 days starvation, $2.5 \times 10^{-3} \%$ cells were culturable, but no increase in cell number was observed. During starvation, the exopolymer concentration remained constant, an indication that the exopolymer was not consumed by the starving bacteria as an alternative carbon or energy source.
\end{abstract}

\section{Introduction}

Understanding microbial activity in the subsurface (aquifer and oil reservoir) is important for engineering applications such as subsurface bio-barriers, in situ

D.-S. Kim · H. S. Fogler $(\bowtie)$

Department of Chemical Engineering, University of Michigan,

2300 Hayward Street, Ann Arbor, MI 48109-2136, USA

e-mail: sfogler@umich.edu

Tel.: + 1-734-763-1361

Fax: + 1-734-763-0459 bioremediation and microbial enhanced oil recovery (MEOR). In these applications, model bacterial cells are injected through injection wells into the aquifer or oil reservoir, or indigenous cells are stimulated. When supplied with proper stimulants or nutrients, cells can decontaminate toxic chemicals or produce desirable metabolic byproducts (for example, exopolymers) to modify subsurface permeability. Two issues need to be addressed for the effective control of subsurface biological processes: migration of cells and culturability. Injected cells need to be transported to the area where biological activity should occur, referred to as the target zone, and should be retained in the target zone. Likewise, when stimulating indigenous cells for bioremediation or MEOR, these cells must be immobilized in the target area to effectively carry out the required biological process. In addition to transport, injected or indigenous cells need to maintain culturability to perform the required processes for a long period of time, and cell culturability is addressed in this paper.

Microbial cells can produce extracellular polymers (exopolymers) which lead to biofilm formation (Vandevievere and Baveye 1992). Biofilms formed by exopolymers can lead to a decrease in permeability thereby restricting fluid flow and cell transport in porous media (Lappan and Fogler 1996; Peyton 1996). The decrease in permeability in the flow path can also restrict nutrient flow into the target area and cause bacterial starvation in the target area. Starvation of bacteria slows down bacterial metabolism and causes cell death which can terminate biological processes in the target area. Bacterial starvation can also occur in cells residing in biofilms because the cells near a solid surface may be deprived of nutrients due to diffusion limitations (Applegate and Bryers 1991).

In order to understand the effects of bacterial starvation on culturability and cell morphology in the presence of exopolymers, cells were starved with and without the presence of exopolymers. Leuconostoc mesenteroides NRRL B-523 (ATCC 14935) was used 
because the exopolymer production mechanism of L. mesenteroides has been well studied (Lappan and Fogler 1994; Jeanes et al. 1954), and it has been suggested as a candidate for subsurface operations (Lappan and Fogler 1992; Xiu-Yuan and Wang 1991).

\section{Materials and methods}

Batch experiments were carried out to determine how bacteria respond to carbon source depletion with and without the presence of exopolymers after exponential growth has ended. Three analyses were performed: (1) cell culturability, (2) cell morphology, and (3) water-soluble and insoluble exopolymer concentrations.

\section{Bacterial strains}

L. mesenteroides NRRL B-523 (ATCC 14935) was used as a model bacterium. The Leuconostoc is classified as a member of the Lactobacillus family, and is Gram positive. It is spherical $(0.5-1.2 \mu \mathrm{m})$ and forms long chains during growth. It is facultatively anaerobic (Holzapfel and Schillinger 1981) and known to produce extracellular polysaccharides (dextran) when fed sucrose (Jeanes et al. 1954; Lappan and Fogler 1992; van Geel-Schutten et al. 1998). Dextran is composed of glucose monomers mainly linked by $\alpha-1,6-$ glucosidic bonds with 1-3 and 1-4 branches.

\section{Growth and starvation media}

The medium used to grow the inoculum, L. mesenteroides, was a combination of yeast extract $(1 \mathrm{wt} \%), \mathrm{NaCl}(0.07 \mathrm{M}), \mathrm{NH}_{4} \mathrm{Cl}$ $(0.06 \mathrm{M}), \mathrm{CH}_{3} \mathrm{COONa}(0.06 \mathrm{M})$, ascorbic acid $\left(0.5 \mathrm{~g} / \mathrm{dm}^{3}\right)$, trace minerals and a carbon source (sucrose or a combination of glucose and fructose $(\mathrm{G}+\mathrm{F}), 0.1 \mathrm{M})$ in a phosphate-buffered saline solution. Sucrose and a combination of $(\mathrm{G}+\mathrm{F})$ were used as carbon and energy sources. These carbon sources were chosen because a significant amount of water-insoluble exopolymers is produced with sucrose, whereas no exopolymer production by $L$. mesenteroides has been reported when fed $(\mathrm{G}+\mathrm{F})$. Growth kinetics of $L$. mesenteroides are virtually the same in each case when two carbon sources are stoichiometrically equivalent (Lappan and Fogler 1994). The trace minerals were a combination of $\mathrm{Mg}, \mathrm{Mn}$, and $\mathrm{Fe}$. The final concentration of trace minerals in the growth and starvation media was $12.7 \mu \mathrm{M}$ for $\mathrm{MnSO}_{4}, 10 \mu \mathrm{M}$ for FeSO4 $7 \mathrm{H}_{2} \mathrm{O}$ and $100 \mu \mathrm{M}$ for $\mathrm{MgSO}_{4} \cdot 7 \mathrm{H}_{2} \mathrm{O}$. More detailed information on the growth medium can be found in Lappan and Fogler (1994).

The starvation medium consisted of a $0.1 \mathrm{M}$ solution of $\mathrm{NaCl}$ with the same concentrations of trace minerals as growth medium in a phosphate-buffered saline solution. $\mathrm{NaCl}$ was added to maintain the same osmotic pressure as the growth medium.

\section{Procedure}

L. mesenteroides cultured at the end of the exponential growth phase was inoculated into two $1000-\mathrm{ml}$ batch reactors at room temperature. The initial cell concentration was approximately $10^{5}$ cells $/ \mathrm{ml}$. One reactor contained sucrose and the other had the G+F combination as carbon sources. The experiments were performed at a constant temperature of $25^{\circ} \mathrm{C}$. Batch reactors were shaken slowly ( $\sim 60 \mathrm{rev} / \mathrm{min})$ for $1 \mathrm{~min}$ every $4 \mathrm{~h}$ during growth. A sample $(500 \mathrm{ml})$ was taken from each reactor at the end of the exponential growth phase $(20 \mathrm{~h}$ after inoculation) and was centrifuged $(6000 \mathrm{~g})$ for 20 min to separate the cells. The cells collected at the bottom of the vial were washed twice with phosphate-buffered saline solution and transferred to $500 \mathrm{ml}$ of the starvation medium. The $\mathrm{pH}$ of the starvation medium was adjusted to $4.6( \pm 0.02)$ before transferring cells from the growth medium because the $\mathrm{pH}$ of the growth medium decreased from 6.5 to 4.6 during the growth phase.
Viability assay

Spread-plate counting with MRS agar plates (a mixture of MRS broth (dehydrated, Difco) and agar (granulated, Difco)) was used to measure the number of colony-forming units (CFU) during starvation. Samples $(1 \mathrm{ml})$ were taken every $4-6 \mathrm{~h}$ during the $1 \mathrm{st}$ week of starvation, once a day during the 2 nd week, and once every 2 days for the remainder of the experiments. The samples were incubated at $30{ }^{\circ} \mathrm{C}$ for 1.5 days before counting.

\section{Morphology assay}

The cell diameter was measured using a fluorescent microscope (Zeiss, Axioskop fluorescence microscope with Achroplan lens $100 \times / 1.25$ oil). The cells were stained with the Viability Kit (Molecular Probes) according to a procedure provided by Molecular Probes (Haugland 1996), and the microscopic image was transferred to a computer using a CCD camera. The cell size (diameter) was measured using image analysis software or photographic methods (Fry 1990). To obtain statistically valid results for cell size distributions, at least 200 bacteria were counted in at least ten randomly chosen fields $(\times 1000$ magnification $)$. Because L. mesenteroides is know to form long chains (Holzapfel and Schillinger 1981), a Coulter Counter (model ZF, Coulter Electronics) was used to measure the number of cell chains and the chain size.

\section{Exopolymer assay}

Water-soluble and insoluble exopolymer concentrations were monitored during growth and starvation. Because the exopolymer is a glucose polymer chain, the exopolymer concentration was measured by degrading this glucose polymer into glucose monomers and assaying the glucose concentration with a phenol-sulfuric acid assay (Chaplin and Kennedy 1994).

Prior to glucose analysis (phenol-sulfuric acid assay), separation and hydrolysis of the soluble and insoluble exopolymers were carried out according to the procedures described in Jeanes (1965): aliquots of sample $(5 \mathrm{ml})$ were taken from the batch reactors, and centrifuged $(6000 \mathrm{~g})$ for $20 \mathrm{~min}$ to separate insoluble and soluble parts. After $20 \mathrm{~min}$ centrifugation, an insoluble biomass pellet (insoluble exopolymers and cells) had collected at the bottom. The supernatant (soluble exopolymers and metabolic byproducts) was saved for the soluble exopolymer assay. The pellet was rinsed with deionized water and centrifuged again. To separate the cells from the insoluble exopolymer, a $10 \% \mathrm{KOH}$ solution was added to dissolve the exopolymer, while keeping the cells intact. The cells and dissolved exopolymer were separated by centrifugation, and the supernatant (insoluble exopolymers dissolved in $\mathrm{KOH}$ ) was saved for further processing. The suspensions were treated with an excess of $100 \%$ ethanol, to precipitate out the soluble exopolymer and dissolved insoluble exopolymers. The precipitates were filtered with a $0.2-\mu \mathrm{m}$ nylon filter (Cole-Parmer) and the filter paper was rinsed with $100 \%$ ethanol. Precipitated soluble and insoluble exopolymers were treated in the following manner. Hydrochloric acid ( $2 \mathrm{M}$ ) was added to the precipitates to adjust the $\mathrm{pH}$ to $1-2$, and the solution was boiled for $3 \mathrm{~h}$ in a water bath with caps tightly closed. After boiling, the $\mathrm{pH}$ of the sample was adjusted to 6.5 with $10 \%$ $\mathrm{KOH}$. This solution was then assayed for glucose using phenolsulfuric acid assay using UV spectroscopy at wave length $490 \mathrm{~nm}$.

\section{Results}

\section{Cell size}

The average initial cell diameter at the beginning of starvation was $0.8( \pm 0.048) \mu \mathrm{m}$. The cell diameter decreased during starvation, eventually leveling off at 
approximately $0.35( \pm 0.023) \mu \mathrm{m}$. The average cell diameter for sucrose-fed cells and $(\mathrm{G}+\mathrm{F})$-fed cells is shown as a function of starvation time in Fig. 1. In both cases, the average cell diameter decreased for 3 days after starvation began and then remained constant for the remainder of the experiment. Within experimental error, no significant differences in cell diameter between sucrose- and $(\mathrm{G}+\mathrm{F})$-fed cases were observed.

\section{Cell chain length}

Cell chain length distributions were measured using a Coulter Counter (Figs. 2 and 3). The distribution curves for both sucrose- and $(\mathrm{G}+\mathrm{F})$-fed cells during the growth phase before starvation show a typical pattern for chain forming cells as two nodes were observed in Figs. 2 and 3 . As cells grew after the lag phase $(6 \mathrm{~h})$, the cell chain length increased. Fluorescence microscopy revealed an average of 4-6 cells per chain during the growth phase. As a result, two nodes appeared in cell chain size distribution; one for smaller size cell chains at $0.8 \mu \mathrm{m}$, and the other for larger size cell chains at $1.3-1.8 \mu \mathrm{m}$. The peaks for larger cell chains increased as more cells formed longer chains during growth. Differences in the evolution pattern of the cell chain distribution were observed between the sucrose- and the $(\mathrm{G}+\mathrm{F})$-fed cells. For the sucrose-fed cells (Fig. 2), the peak at $0.8 \mu \mathrm{m}$ continued to increase, while the peak for larger chains at $1.3 \mu \mathrm{m}$ shifted to the left until the two peaks become one after a period of 10 days. In addition, the peaks shifted to lower values as they became sharper and larger up to day 20 , after which the peak showed virtually no change for the remainder of the experiment.

The changes in the peak position indicated that the large cell chains break into small cell chains for 20 days. For the $(\mathrm{G}+\mathrm{F})$-fed cells (Fig. 3), the two peaks merged more rapidly in less than 1 day, then the single peak

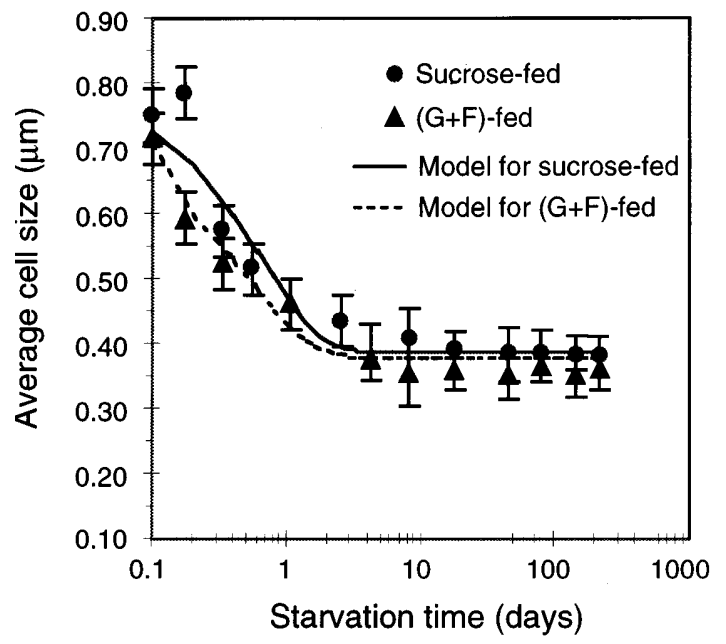

Fig. 1 Average size of cells measured using fluorescent microscopic images for sucrose-fed and glucose and fructose $(G+F)$-fed cells

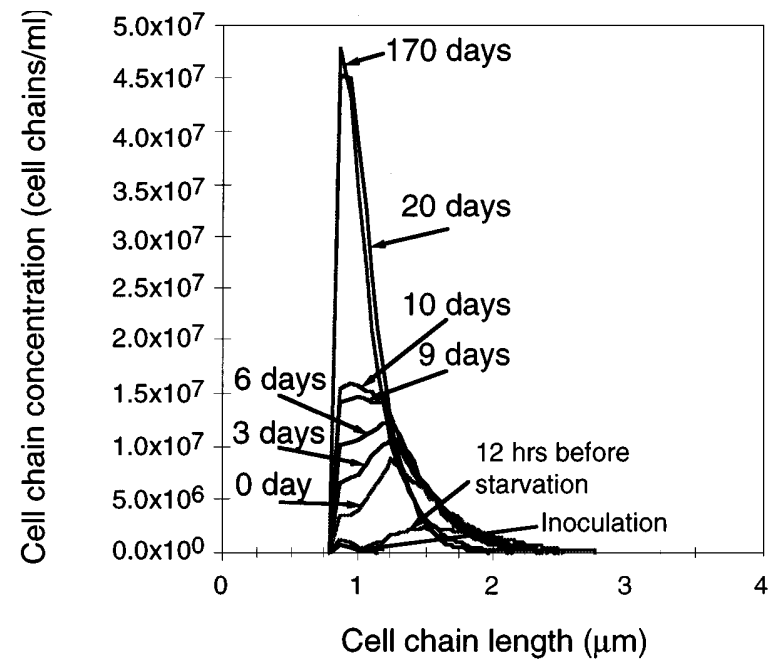

Fig. 2 Cell chain distribution for sucrose-fed cells

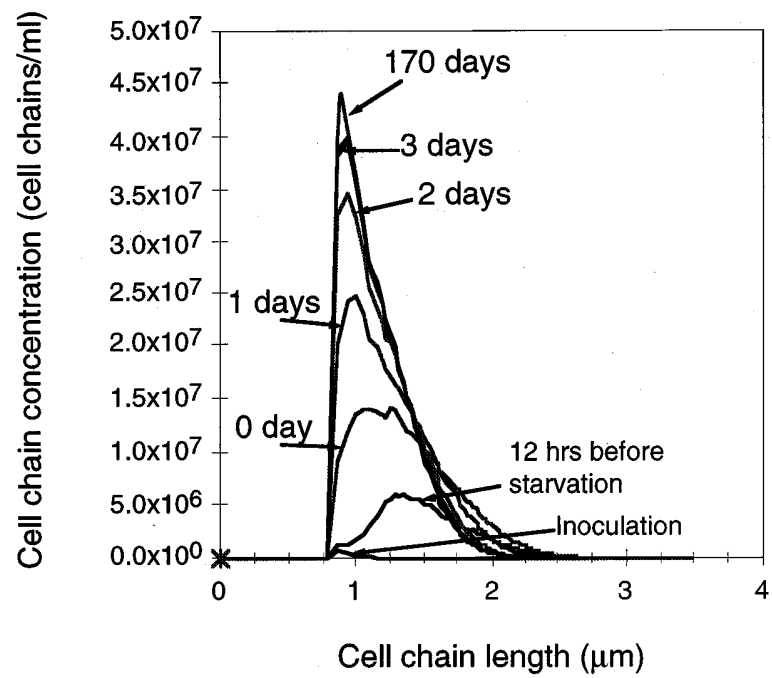

Fig. 3 Cell chain distribution for $(\mathrm{G}+\mathrm{F})$-fed cells

became larger and sharper as it shifted to the lower cell size as the cell chains fragmented into smaller chains. The break down of longer cells continued up to 6 days, after which the cell chain number remained essentially constant. The different evolution pattern of cell chain distribution is due to the presence of exopolymers as explained in the discussion section.

\section{Cell culturability}

Cells transferred from the sucrose-fed batch showed a greater culturability than those from the $(\mathrm{G}+\mathrm{F})$-fed batch (Fig. 4). After starvation started, the culturable cell count, reported as CFU, remained constant for approximately 5 days for sucrose-fed cells, and for 1 day for the $(\mathrm{G}+\mathrm{F})$-fed cells. For both the sucrose-fed and $(\mathrm{G}+\mathrm{F})$-fed cells, the CFU levels off after approxi- 


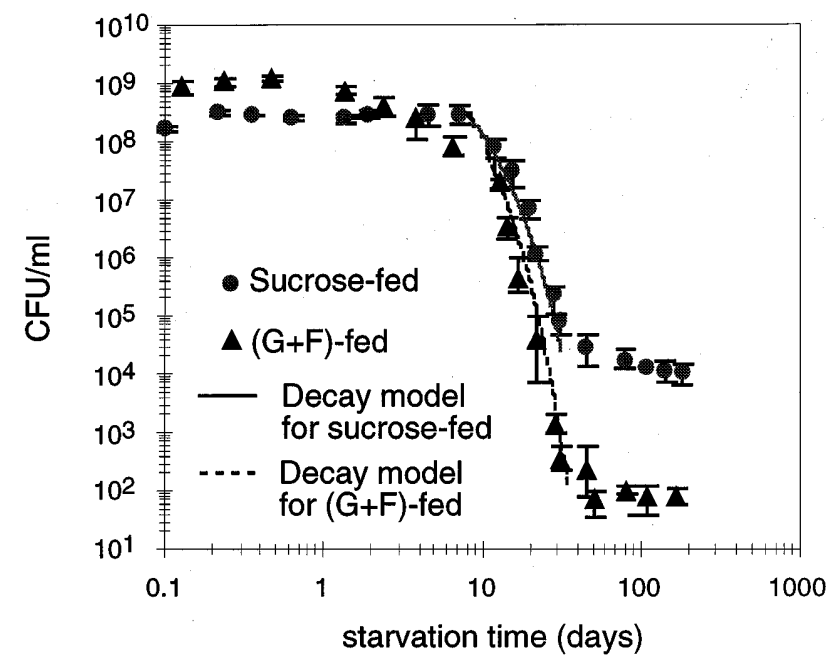

Fig. 4 Colony-forming unit (CFU) measurements for sucrose-fed and $(\mathrm{G}+\mathrm{F})$-fed cases

mately 60 days starvation. The CFU of $(\mathrm{G}+\mathrm{F})$-fed cells decreased faster than sucrose-fed cells, eventually leveling off at $200 \mathrm{CFU} / \mathrm{ml}$, whereas the $\mathrm{CFU}$ of sucrose-fed cells leveled off at approximately $5000 \mathrm{CFU} / \mathrm{ml}$. Some cells were still culturable after 200 days starvation. The $\mathrm{CFU}$ for both cases remained constant throughout the remainder of the experiment under starvation conditions.

\section{Exopolymer assay}

No significant insoluble exopolymer was detected during the starvation of the $(\mathrm{G}+\mathrm{F})$-fed cells, whereas $0.09 \mathrm{~g} / \mathrm{dm}^{3}$ $\left( \pm 0.02 \mathrm{~g} / \mathrm{dm}^{3}\right)$ of insoluble exopolymer was measured for sucrose-fed cells. The concentration of insoluble exopolymers produced during growth was $0.09 \mathrm{~g} / \mathrm{dm}^{3}$ under sucrose-fed conditions. Soluble exopolymers were also detected during the growth phase for both the sucrose and $(\mathrm{G}+\mathrm{F})$-fed cases. Soluble exopolymer concentrations under sucrose-fed conditions were $0.3 \mathrm{~g} / \mathrm{dm}^{3}$ and were $0.45 \mathrm{~g} / \mathrm{dm}^{3}$ under $(\mathrm{G}+\mathrm{F})$-fed conditions. When cells were centrifuged at the end of the exponential growth phase and transferred to the starvation medium, no soluble exopolymer was transferred, although insoluble exopolymer was transferred with the cells. The exopolymer concentration was monitored throughout the starvation experiments, but no change in exopolymer concentration was observed with respect to starvation time.

\section{Discussion}

The cell diameter, cell chain length and viability were examined during starvation under two different conditions: the presence and the absence of insoluble exopolymers. Decreases in cell diameter and cell chain length were observed during starvation for both cases.
In order to quantify the effect of exopolymers on the rate of cell diameter decrease, the average cell size during starvation was modeled with a first order exponential decay model using linear regression:

$d=d_{\mathrm{s}}+a \exp \left(-k_{\mathrm{ds}} t_{\mathrm{s}}\right)$

where $d=$ cell size during starvation $(\mu \mathrm{m}), d_{\mathrm{s}}=$ final cell size after long-term starvation $(\mu \mathrm{m}), t_{\mathrm{s}}=$ starvation time (days), $k_{\mathrm{ds}}=$ starvation decay parameter for cell size (per day), $a=$ coefficient for initial cell size $\left(d_{\mathrm{o}}=d_{\mathrm{s}}+a\right)(\mu \mathrm{m})$.

Figure 5 shows sample data for this model. The rate of decrease of the cell diameter can be compared using the parameter, $k_{\mathrm{ds}}($ Table 1$)$. The $k_{\mathrm{ds}}$ for $(\mathrm{G}+\mathrm{F})$-fed cells is larger than that for sucrose-fed cells which means that $(G+F)$-fed cells shrink faster than sucrose-fed cells. The difference in the rate of decrease in cell size is due to the presence of exopolymers. Cell shrinkage is known to cause an increase in the surface area to volume ratio which helps sequester nutrients more efficiently in a lownutrient environment (Poindexter 1981). In addition, exopolymers are known to help cells store nutrient and trace minerals inside and outside the cell (Costerton et al. 1978). Therefore, with exopolymers (i.e. sucrosefed cells), L. mesenteroides can survive using nutrients stored outside and, as a result, the cell size decreases less rapidly.

The effects of exopolymer were also observed in studies on cell culturability under starvation conditions. Cells undergoing starvation in the presence of exopolymers (sucrose-fed) showed a larger number of culturable cells than the $(\mathrm{G}+\mathrm{F})$-fed cells. Considering that the only difference between the two starvation systems is the presence of insoluble exopolymers, these exopolymers are the major reason for the better survival of the bacteria during long-term starvation. Some bacterial species are known to degrade exopolymers when deprived of carbon sources (Walker and Pulkownik 1973). Therefore, it is possible that survival during long-term star-

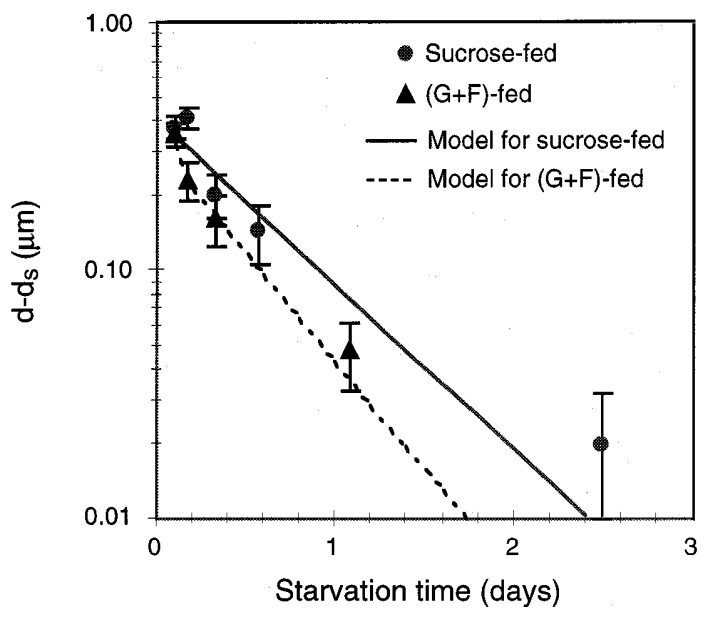

Fig. 5 Data fitting with a first order decay model for cell diameter decrease during starvation 
Table 1. Cell size model parameters. $\left(\mathrm{R}^{2}\right.$ : coefficient of determination $\left(0<\mathrm{R}^{2}<1\right)$, $\mathrm{R}^{2}=1$ : perfect fitting, $\mathrm{R}^{2}=0$ : no fitting)

\begin{tabular}{lll}
\hline Parameter & $\begin{array}{l}\text { Sucrose-fed cells } \\
\left(\mathrm{R}^{2}=0.89\right)\end{array}$ & $\begin{array}{l}\text { (Glucose and Fructose)-fed cells } \\
\left(\mathrm{R}^{2}=0.84\right)\end{array}$ \\
\hline Final cell size after starvation $d_{\mathrm{s}}(\mu \mathrm{m})$ & $0.37( \pm 0.012)$ & $0.38( \pm 0.019)$ \\
Starvation decay of cell size $k_{\mathrm{ds}}($ per day) & $1.54( \pm 0.102)$ & $2.02( \pm 0.103)$ \\
Initial cell size coefficient $a(\mu \mathrm{m})$ & $0.41( \pm 0.038)$ & $0.32( \pm 0.037)$ \\
Starvation time midpoint $t_{1 / 2}$ (days) & 2.73 & 2.31 \\
\hline
\end{tabular}

vation could result from exopolymer degradation. However, exopolymer consumption did not occur, because no change in exopolymer concentration was observed during 200 days starvation.

The rate of cell decay was calculated using the data in Fig. 6, showing a rapid CFU number decrease (death phase). A first order decay model was used to obtain the decay kinetic parameters.

$C=C_{\mathrm{o}} \exp \left(-k_{\mathrm{cs}} t_{\mathrm{s}}\right)$

where $C=$ the concentration of live chains during starvation $(\mathrm{CFU} / \mathrm{ml}), C_{\mathrm{o}}=$ the initial number of $\mathrm{CFU}$ in the starvation phase $(\mathrm{CFU} / \mathrm{ml}), k_{\mathrm{cs}}=$ the starvation kinetic parameter for cell viability (per day), $t_{\mathrm{s}}=$ starvation time (days).

The $k_{\mathrm{cs}}$ of $(\mathrm{G}+\mathrm{F})$-fed cells $(0.55$ per day $)$ was about 1.5 times larger than that of sucrose-fed cells $(0.37$ per day). Therefore, exopolymers not only help cells survive better in long-term starvation, but they also slow down cell decay during the death phase.

Both Coulter Counter measurements (Figs. 2 and 3) and fluorescence microscopy observations revealed cell chain formation during growth and cell chain fragmentation during starvation. The change in cell chain distribution with respect to starvation time differs depending on whether or not exopolymers are present. The decrease in the number of large cell chains and increase in the number of small cell chains during starvation is a result of the long cell chains (4-6 cells)

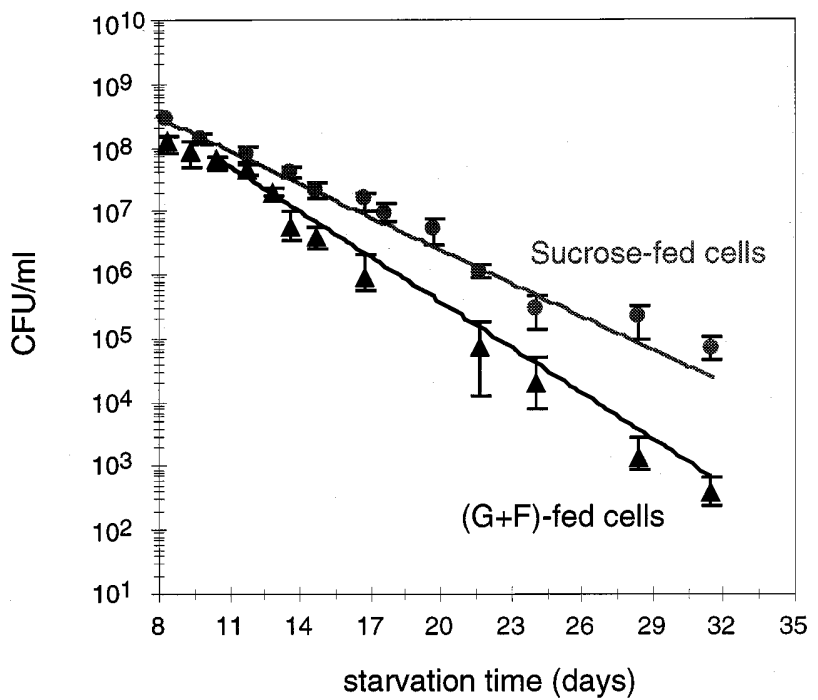

Fig. 6 The concentration of cell chains measured using Coulter Counter for sucrose-fed and $(\mathrm{G}+\mathrm{F})$-fed cells breaking into short chains (1-2 cells). This phenomenon can be compared more clearly if the number of cell chains is calculated with respect to starvation time. The area underneath the curves (Figs. 2 and 3) represents the number of cell chains. The increase in the number of cell chains during starvation was due to cell chain fragmentation, not cell growth (Fig. 7). For $(G+F)$-fed cells, the cell chain concentration increased rapidly for about 1 day after starvation began, whereas for sucrosefed cells the concentration increased slowly for approximately 9 days. The slow cell chain fragmentation of sucrose-fed cells resulted from the presence of waterinsoluble exopolymers surrounding the cell chains, which held the cell chains together more tightly. Considering that larger cells are more easily trapped in small pores during transport in porous media, cell chain fragmentation would facilitate cell transport through porous media thereby enhancing deep penetration for uniform cell distribution in a target area. The effects of exopolymers on cell chain fragmentation was clearly observed in this study and these effects need to be accounted for when developing injection strategies for better cell transport.

In summary, the average cell diameter decreased from $0.8( \pm 0.048) \mu \mathrm{m}$ to $0.35( \pm 0.023) \mu \mathrm{m}$ during starvation. The slower decrease in cell diameter with exopolymers is attributed to nutrient storage within exopolymers. The rate of cell chain fragmentation is smaller in the presence of water-insoluble exopolymers than without exopolymers because the exopolymer network structure holds

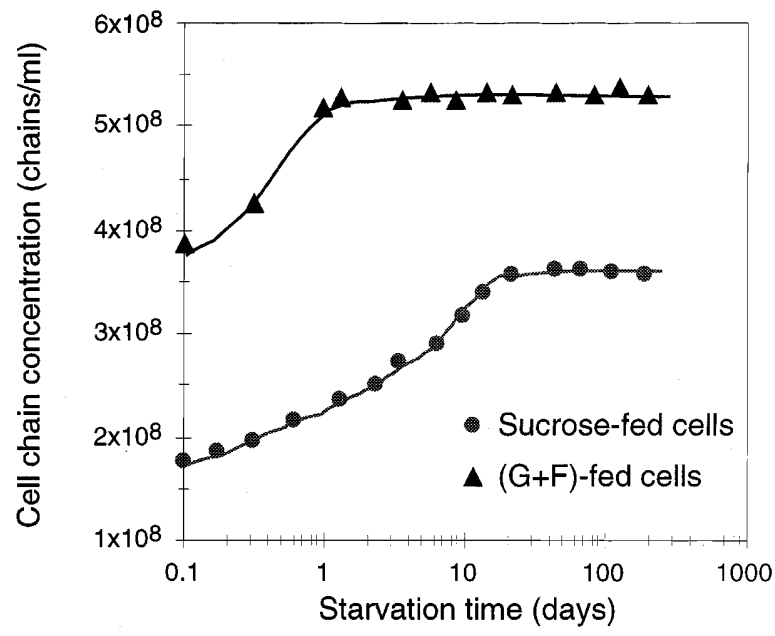

Fig. 7 Data fitting with a first order decay model for the decrease in culturable cell concentration during starvation 
the cell chains together. L. mesenteroides showed a greater culturability and lower death rate in the presence of exopolymers. The decrease in cell size can better facilitate cell transport (Watanabe 1996). In addition to cell size reduction, the fragmentation of cell chains during starvation can also facilitate cell transport in low permeability porous media. Survival of $L$. mesenteroides after long-term starvation is beneficial for maintaining bioprocesses for a long period of time under nutrientpoor conditions. The death rate and proportion of live cells determined in the starvation experiments can be used to help design injection strategies for bacterial transport in the subsurface.

\section{References}

Applegate DH, Bryers JD (1991) Effects of carbon and oxygen limitations and calcium concentrations on biofilm removal processes. Biotechnol Bioeng 37: 17-25

Chaplin MF, Kennedy JF (1994) Carbohydrate analysis. 2nd edn. Oxford University Press, Oxford

Costerton JW, Geesey GG, Cheng K-J (1978) How bacteria stick. Sci Am 238: 86-95

Fry JC (1990) Direct methods and biomass estimation. In: Grigorova R (ed) Methods in microbiology, vol 22. Academic Press, New York, pp 41-85

Haugland RP (1996) Handbook of fluorescent probes and research chemicals. 6th edn. Molecular Probes, The Netherlands

Holzapfel WH, Schillinger U (1981) The genus Leuconostoc. In: Starr MP (ed) The prokaryotes: a handbook on habitats, isolation, and identification of bacteria. Springer, Berlin Heidelberg New York, pp 1508-1534
Jeanes A (1965) Preparation of dextrans from growing Leuconostoc cultures. In: Whistler RL, BeMiller JN, Wolfrom ML (eds) Methods in carbohydrate chemistry. Academic Press, New York, pp 118-127

Jeanes A, Haynes WC, Wilham CA, Rankin JC, Melvin EH, Austin MJ, Cluskey JE, Fisher BE, Tsuchiya HM, Rist CE (1954) Characterization and classification of dextran from ninety-six strains of bacteria. J Am Chem Soc 76: 5041-5052

Lappan RE, Fogler HS (1992) Effect of bacterial polysaccharide production on formation damage. Soc Pet Eng J 7: 167-171

Lappan RE, Fogler HS (1994) Leuconostoc mesenteroides growth kinetics with application to bacterial profile modification. Biotechnol Bioeng 43: 865-873

Lappan RE, Fogler HS (1996) Reduction of porous media permeability from in situ Leuconostoc mesenteroides growth and dextran production. Biotechnol Bioeng 50: 6-15

Peyton BM (1996) Improved biomass distribution using pulsed injections of electron donor and acceptor. Water Res 30: 756758

Poindexter JS (1981) Oligotrophy: fast and famine existence. Adv Microbiol Ecol 5: 63-90

Vandevivere P, Baveye P (1992) Effect of bacterial extracellular polymers on the saturated hydraulic conductivity of sand columns. Appl Environ Microbiol 58: 1690-1698

van Geel-Schutten GH, Flesch F, ten Brink B, Smith MR, Dijkhuizen L (1998) Screening and characterization of Lactobacillus strains producing large amounts of exopolysaccharides. Appl Microbiol Biotechnol 50: 697-703

Walker GJ, Pulkownik A (1973) Degradation of dextrans by an $\alpha$ 1,6-glucan glucohydrolase from Streptococcus mitis. Carbohydr Res 29: 1-14

Watanabe ME (1996) Starved bacteria investigated as bioremediation, biobarrier technology. Environ Sci Technol 30: 333A

Xiu-Yuan W, Wang XY (1991) Advances in research, production and application of biopolymers used for EOR in China. In: Donaldson EC (ed) Microbial enhancement of oil recovery recent advances. Elsevier, Amsterdam, pp 467-481 